\title{
Microwave Sintering of Mullite-Al2O3 from Kaolin Precursor
}

\author{
Lilian Cecilia Reinoso Navarro ${ }^{a}$, Romualdo Rodrigues Menezes ${ }^{b}$, \\ Ruth Herta Goldschmidt Aliaga Kiminami ${ }^{a *}$ \\ ${ }^{a}$ Department of Materials Engineering, Federal University of São Carlos - UFSCar, \\ CEP 13565-905, São Carlos, SP, Brazil \\ ${ }^{b}$ Department of Materials Engineering, Federal University of Campina Grande - UFCG, \\ CEP 58429-140, Campina Grande, PB, Brazil
}

Received: March 13, 2014; Revised: December 10, 2014

In the present work the effect of the microwave hybrid fast sintering of mullite- $\mathrm{Al}_{2} \mathrm{O}_{3}$ with nonstoichiometric mullite composition was investigated. Samples were fast sintered using a range of microwave power from 1.2 to $2.1 \mathrm{~kW}$. The mullitization process of the silica-rich composition was faster than that of the alumina-rich composition. Alumina-rich mullite showed higher densities and smaller grain size than alumina-poor mullite. It was concluded that the microwave hybrid sintering of mullite was very sensitive to composition.

Keywords: mullite, microwave heating, fast sintering, microstructure

\section{Introduction}

Mullite has gained increasing importance as a material for both traditional and advanced ceramics. Mullite displays various $\mathrm{Al}$ to $\mathrm{Si}$ ratios in solid solution $\mathrm{Al}_{4+2 X} \mathrm{Si}_{2-2 X} \mathrm{O}_{10-X}$, with $x$ ranging from about 0.2 to 0.9 (55 to $90 \mathrm{~mol} \% \mathrm{Al}_{2} \mathrm{O}_{3}$ ) ( $\mathrm{x}$ denotes the number of missing oxygen atoms) ${ }^{[1,2]}$. The stoichiometric mullite $3 \mathrm{Al}_{2} \mathrm{O}_{3} \cdot 2 \mathrm{SiO}_{2}(\mathrm{x}=0.25)$ corresponds to $71.8 \mathrm{wt} \%$ alumina ${ }^{3,4}$. The performance of mullite ceramics is determined by their chemical composition and sintered microstructure ${ }^{4,5}$.

The outstanding scientific and technical importance of mullite can be explained by its high thermal stability and its favorable properties such as low thermal expansion and conductivity, high creep resistance and corrosion stability, allied to suitable strength and fracture toughness ${ }^{1,2,6}$. Mullite is an advantageous material for construction and engineering ceramics, refractories, kiln furniture, creep resistant materials, substrates for catalytic converters, electronic devices, and is also a major component in porcelain materials ${ }^{1,7}$.

Several reports have discussed the preparation of mullite ceramics. Mullite is produced synthetically for most applications, following various routes, with a predominance of reaction sintering of alumina and silica precursors ${ }^{4}$. The most cost effective processing route and standard method to prepare mullite involves heating kaolinite to high temperatures with the required amount of $\mathrm{Al}_{2} \mathrm{O}_{3}{ }^{[8-10]}$. Microstructural changes take place in the kaolinite-alumina system during heating. These transformations are not only influenced by the chemical composition but also by processing conditions, e.g.,

*e-mail: ruth@ufscar.br heating rate, sintering temperature, duration of heating and atmospheric conditions ${ }^{11}$.

Rapid heating has been reported to have beneficial effects on the microstructure of ceramics, such as maintaining relatively fine microstructures compared with slow heating for similar densities and higher final densities ${ }^{12-14}$. Conventional fast firing, however, poses some difficulties. Differential heating that causes differential densification is one of the problems often encountered in conventional fast firing. In this context, microwave sintering has emerged in recent years as an alternative technique for processing ceramic materials because it is a noncontact technique, and the heat is transferred to the product via electromagnetic waves, the heat can be transferred uniformly into the material, minimizing the effects of differential densification ${ }^{15}$. In addition, the chemical reactions are enhanced and densification processes accelerated by microwave energy ${ }^{16-23}$.

The synthesis and sintering of mullite ceramics prepared by microwave-assisted reaction sintering of alumina and silica precursors has also been studied ${ }^{11,24}$. According to these reports, mullitization and densification of $\mathrm{Al}_{2} \mathrm{O}_{3}+$ $\mathrm{SiO}_{2}$ powder compacts were faster when using a microwave furnace in comparison to conventional heating, and the mullitization behavior of a mixture of clay and alumina was completed after 20 min of microwave heating ${ }^{11}$. However, the above cited researchers used stoichiometric compositions, and the literature offers scanty information about microwave fast sintering of non-stoichiometric compositions. Therefore, the purpose of this work was to study microwave-assisted hybrid sintering of kaolin and alumina mixtures with non-stoichiometric mullite compositions. 


\section{Experimental Procedure}

Mullite ceramics were prepared by sintering of kaolin Horii and alumina A-1000 from Alcoa as the starting materials. Table 1 lists the chemical composition of alumina $\left(\alpha-\mathrm{Al}_{2} \mathrm{O}_{3}, \mathrm{D}_{50} \approx 0.6 \mu \mathrm{m}\right.$ and $\left.\mathrm{D}_{90} \approx 1.9 \mu \mathrm{m}\right)$ and kaolin (the kaolin was milled before processing, presenting $\mathrm{D}_{50} \approx 1.2 \mu \mathrm{m}$ and $\left.\mathrm{D}_{90} \approx 4.5 \mu \mathrm{m}\right)$. Two powder samples were prepared, one containing $56.83 \%$ of kaolin and $43.17 \%$ of $\mathrm{Al}_{2} \mathrm{O}_{3}$, denoted as $\mathrm{S}$, and the other containing $56.83 \%$ of kaolin and $53.17 \%$ of $\mathrm{Al}_{2} \mathrm{O}_{3}, 10 \%$ more of $\mathrm{Al}_{2} \mathrm{O}_{3}$ denoted as $\mathrm{A}$. The powder was mixed for $2 \mathrm{~h}$ in deionized water and freeze-dried for 48h. Powder compacts ( $10 \mathrm{~mm}$ diameter) were formed by uniaxial pressing under a pressure of $25 \mathrm{MPa}$, followed by cold isostatic pressing under a pressure of $250 \mathrm{MPa}$.

The pressed samples were heat-treated in a microwave furnace (multimode cavity) at $2.45 \mathrm{GHz}$ (Cober Electronics, MS6K) using susceptor materials as auxiliary heating elements. The setup used for microwave hybrid heating is described elsewhere ${ }^{14}$. Input power ranging from 1.2 to $2.1 \mathrm{~kW}$ and sintering times of up to $40 \mathrm{~min}$ were used in the microwave sintering processes. The cooling cycle was not controlled, but the entire microwave sintering (heating and cooling) cycle took less than $1 \mathrm{~h}$.

The bulk density of sintered specimens was measured after $5 \mathrm{~h}$ of boiling and $24 \mathrm{~h}$ of soaking in water, according to the ASTM C373 standard ${ }^{25}$. Phase evaluation was performed by the X-ray diffraction method (Siemens D-5100), using Cu Kalfa radiation ( $40 \mathrm{kV}$ and $40 \mathrm{~mA}$ as working conditions). For a quantitative analysis of the extent of the reaction, the
X-ray diffraction results were compared with XRD data of reference mixtures of known composition. The evolution of mullite formation was examined considering the ratio of the integrated mullite and alumina peak intensities, according the equation used by Piluso ${ }^{26}$. Although the equation considering the degree of mullitization only in stoichiometric mixtures, it was possible to evaluate the evolution of mullite formation in the samples with $10 \%$ excess alumina. The microstructure of sintered specimens was examined by SEM (PHILIPS XL30-FEG) on polished and thermally etched cross sections, $50^{\circ} \mathrm{C}$ below the sintering temperature. Grain sizes were measured using the linear-intercept technique and a stereographic correction factor of 1.56 was performed, using the statistical imaging software Image-Pro Plus version 4.5.0.29.

\section{Results and Discussion}

Figure 1 illustrates the densities of sintered compacts of the compositions $\mathrm{S}$ and $\mathrm{A}$ at different power from 1.2 to $2.1 \mathrm{~kW}$ and sintering times of up to $40 \mathrm{~min}$ in the microwave sintering processes. In both compositions the bulk density increased with sintering time. However, there was a significant difference in the density of compositions $\mathrm{S}$ and A. Compacts of composition A achieved higher densities and their densification behavior was highly dependent on the power output. No direct correlation was found between power output and densification when processing composition A, but the density of composition S compacts increased along with increasing power output. Composition

Table 1. Chemical composition of raw materials.

\begin{tabular}{cccccccccc}
\hline & $\mathrm{SiO}_{2}$ & $\mathrm{Al}_{2} \mathbf{O}_{3}$ & $\mathbf{N a}_{2} \mathbf{O}$ & $\mathbf{M g O}$ & $\mathbf{F e}_{2} \mathbf{O}_{3}$ & $\mathbf{C a O}$ & $\mathbf{K}_{2} \mathbf{O}$ & $\mathbf{T i O}_{2}$ & $\mathbf{L O I}^{\mathbf{b}}$ \\
\hline Kaolin & 46.5 & 38.0 & 0.1 & 0.1 & 0.9 & 0.1 & 1.7 & 0.1 & 12.5 \\
Alumina $^{\mathrm{a}}$ & 0.03 & 99.8 & 0.06 & - & 0.02 & 0.02 & & & - \\
\hline
\end{tabular}

${ }^{a}$ Reported by the manufacturer; ${ }^{\mathrm{b}}$ ooss on ignition.

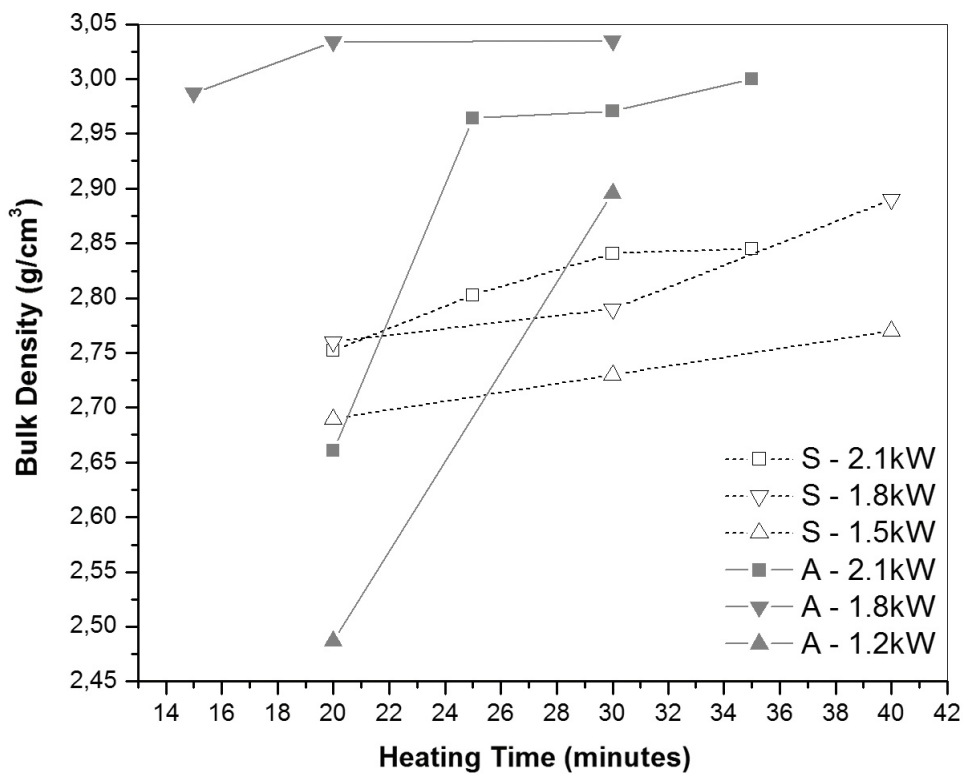

Figure 1. Density of samples sintered within a power range of 1.2 to $2.1 \mathrm{~kW}$. 
A contained 10\% more alumina than composition S, but this higher content sufficed to change the sintering behavior during microwave fast firing.

Figure 2 depicts the X-ray diffraction patterns of sintered compacts. After 20 min of sintering, the only crystalline phases detected in the samples were mullite and alumina. The extent of mullitization was quantified by XRD data of reaction sintered specimens (Figure 3 ). At power outputs of 1.8 and $2.1 \mathrm{~kW}$ and sintering times exceeding $20 \mathrm{~min}$, the mullitization behavior of composition $\mathrm{S}$ was higher than that of composition A. Composition A presented higher densities than composition $\mathrm{S}$, but lower mullitization. Studies ${ }^{3,27}$ of preparation of mullite using reaction sintering have shown that the highest proportion of final density is achieved prior to mullitization, when liquid-phase or liquid-phase-assisted sintering is involved.
Mullite prepared with kaolinite (kaolin) as raw material causes the formation of a glassy phase during processing because kaolinite has a higher $\mathrm{SiO}_{2}$ content than primary mullite, and the excess $\mathrm{SiO}_{2}$ together with the impurities in kaolin form liquid phase during sintering (excess $\mathrm{SiO}_{2}$ is consumed by adding $\mathrm{Al}_{2} \mathrm{O}_{3}$ and the reaction product is a secondary mullite phase). Thus, it seems that the larger amount of liquid phase in composition $\mathrm{S}$ improved the mullitization process, delaying densification. The results illustrated in Figure 4, which are consistent with those reported by Liu et al. ${ }^{25}$, show bimodal grains embedded in amorphous phase and transient liquid phase sintering, thus providing evidence that liquid phase sintering was also due to the characteristics resulting from the co-existence of the glass phase, the rapid kinetics of secondary mullite formation, and the type of microstructure. The results indicate that the main formation mechanism of secondary

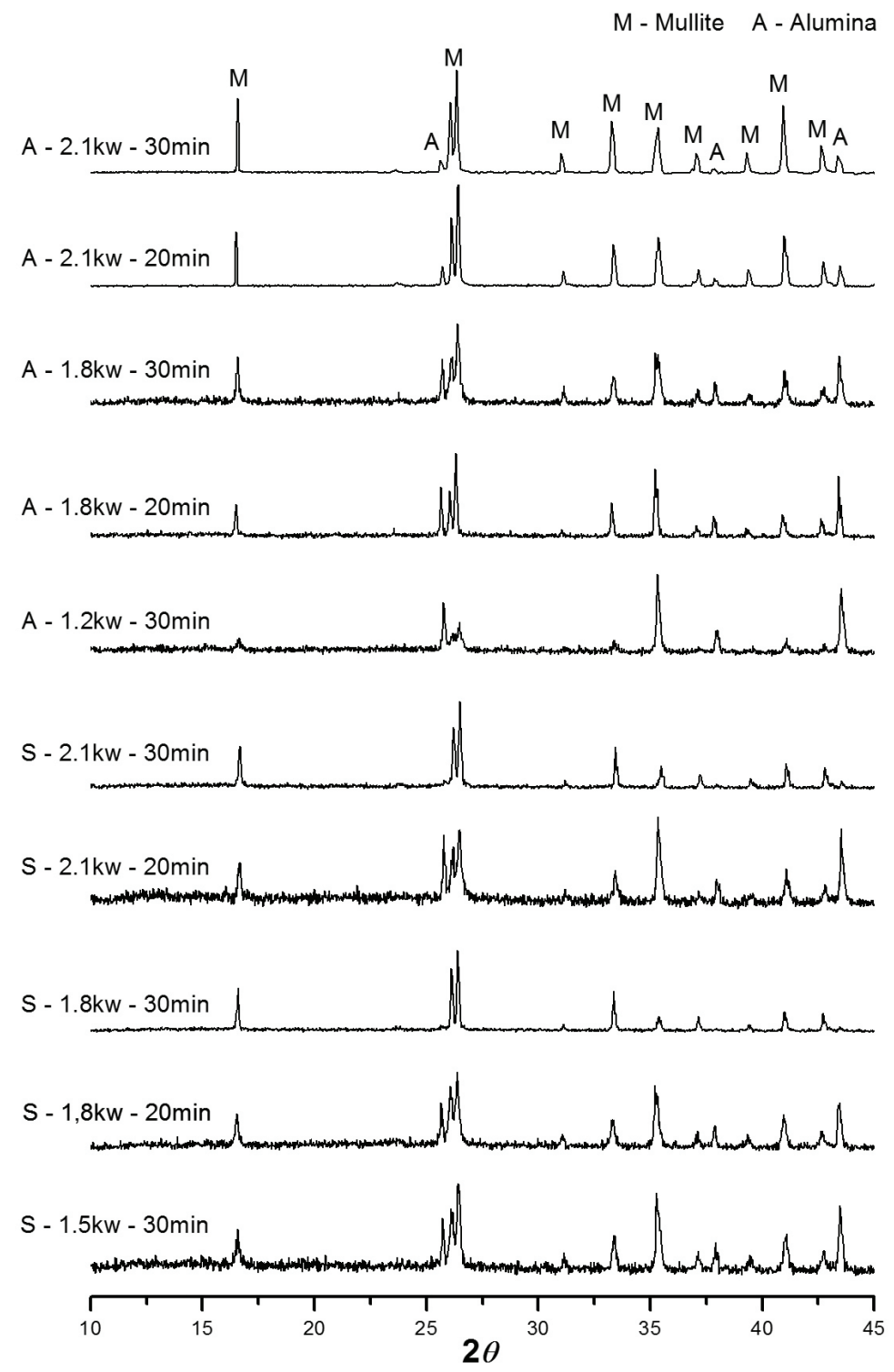

Figure 2. X-ray diffraction patterns of samples A and S sintered for 20 and $30 \mathrm{~min}$ at 1.2, 1.8 and $2.1 \mathrm{~kW}$. 


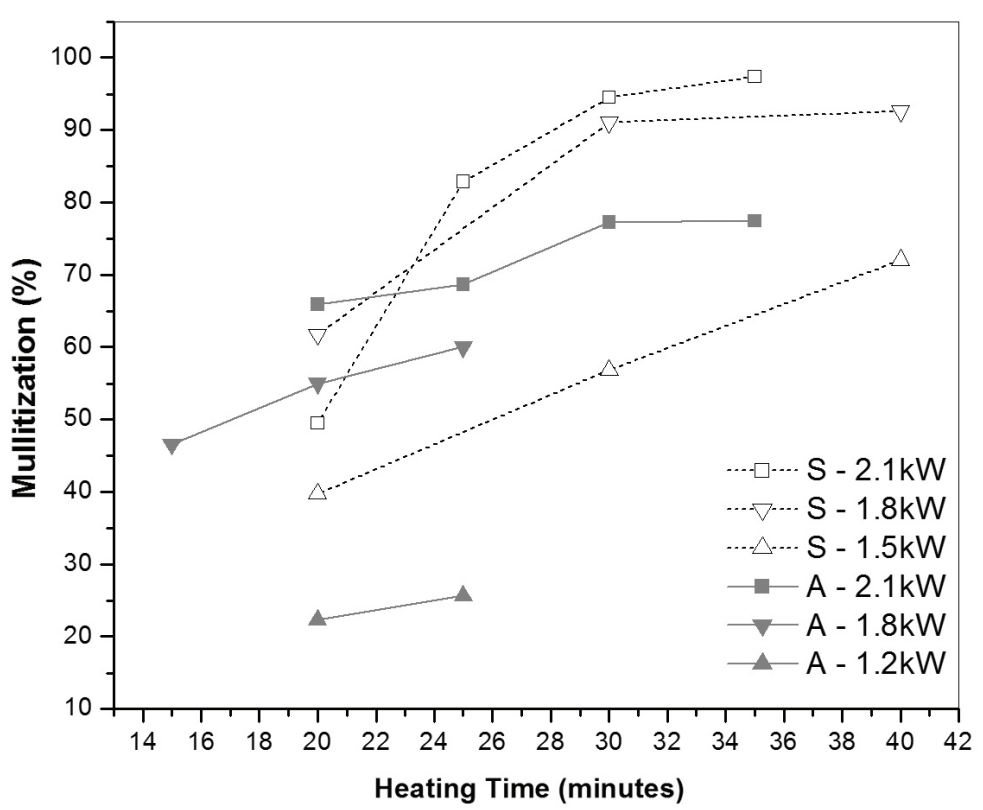

Figure 3. Mullitization as a function of time for samples A and S sintered at 1.2, 1.8 and $2.1 \mathrm{~kW}$.

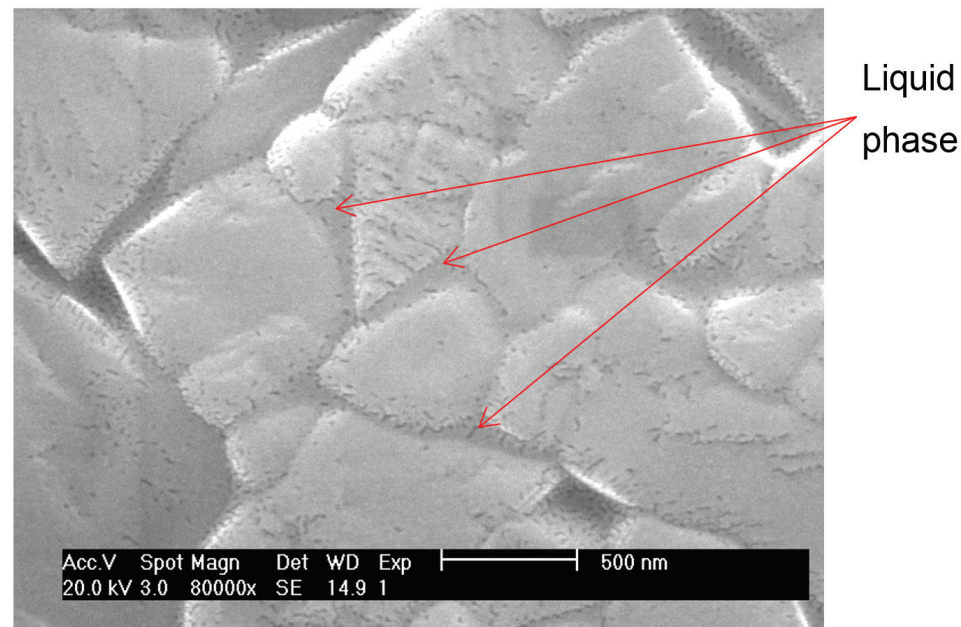

Figure 4. SEM micrographs of composition $\mathrm{S}$ sintered at $2.1 \mathrm{~kW}$ for $20 \mathrm{~min}$.

mullite was dissolution and precipitation via transient liquid phase.

An analysis of the conventional firing of samples in the compositional range under study did not reveal a significant difference in the samples' densification and mullitization behavior. However, kaolinite, mullite and alumina present low dielectric losses, and it is known that the development of liquid phase increases the body's dielectric loss, thus considerably increasing the microwave absorption characteristics of compacts. Other authors ${ }^{27,28}$ have shown that materials with very low dielectric loss display an extremely small, almost negligible difference in densification when processed by microwave energy compared to conventional heating.

Accelerated kinetics has also been reported ${ }^{29}$ for a range of processes in ceramic technology when using microwave energy. Hence, the difference in the microwave fast sintering behavior of compositions S and A may also be related to the presumably higher interaction of composition $\mathrm{S}$ with microwaves due to the lower eutectic temperature expected for this system, which accelerated the reaction kinetics and the development of mullite.

Mullitization may occur at low temperatures during the processing of reaction sintered mullite. However, densification may be difficult even at high temperatures because advanced crystallization of mullite and processing particularities delay complete densification at elevated temperature ${ }^{30}$. However, microwave fast sintered samples of composition $\mathrm{S}$ presented high mullitization and densities.

Figure 5 depicts microstructures of microwave sintered samples, while Table 2 lists the range of grain size distribution. Samples of composition $\mathrm{S}$ presented 


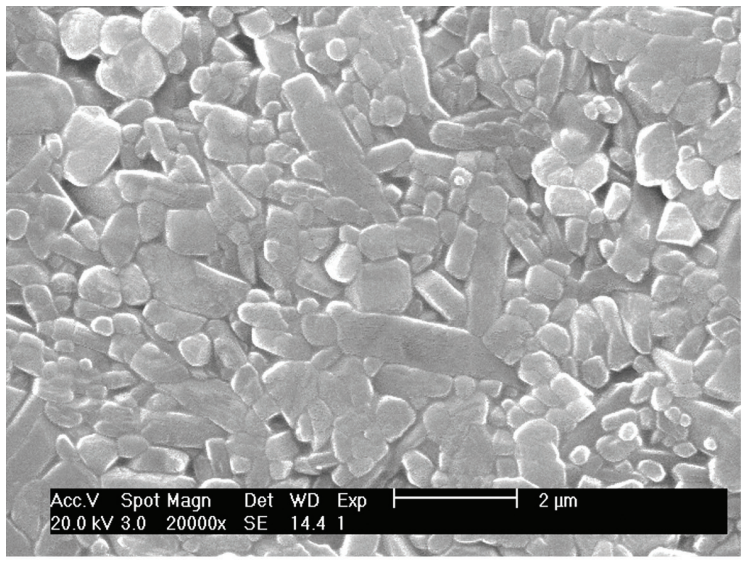

(a)

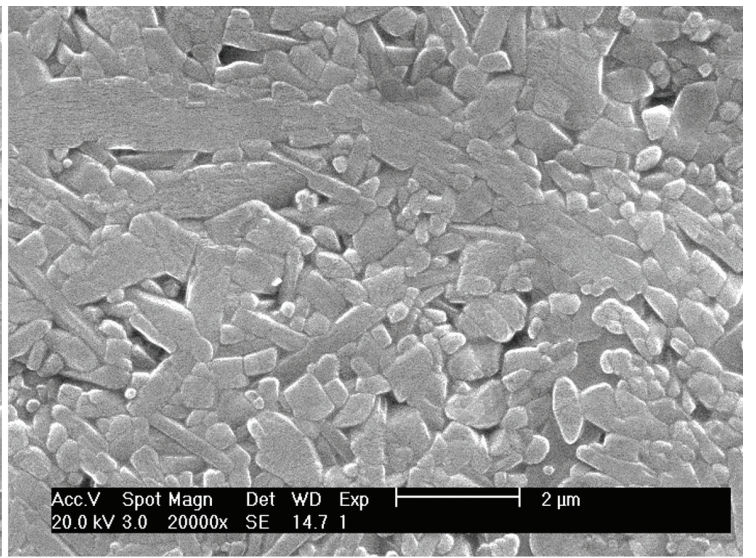

(b)

Figure 5. SEM micrographs of a) composition $\mathrm{S}$ sintered at $2.1 \mathrm{~kW}$ for $35 \mathrm{~min}$. b) composition A sintered at $2.1 \mathrm{~kW}$ for $35 \mathrm{~min}$.

Table 2. Grain size distribution of samples sintered under different conditions for up to $40 \mathrm{~min}$ at $1.2,1.8$ and $2.1 \mathrm{~kW}$.

\begin{tabular}{cccc}
\hline \multicolumn{2}{c}{ Composition $\mathbf{S}$} & \multicolumn{2}{c}{ Composition A } \\
\hline Sintering Condition & Range of Grain Size & Sintering Condition & Range of Grain Size \\
\hline $1.2 \mathrm{~kW}-20 \mathrm{~min}$ & $0.5 \mu \mathrm{m}-0.8 \mu \mathrm{m}$ & $1.2 \mathrm{~kW}-20 \mathrm{~min}$ & $0.4 \mu \mathrm{m}$ to $0.7 \mu \mathrm{m}$ \\
$1.8 \mathrm{~kW}-40 \mathrm{~min}$ & $0.8 \mu \mathrm{m}$ to $2.2 \mu \mathrm{m}$ & $1.8 \mathrm{~kW}-30 \mathrm{~min}$ & $0.6 \mu \mathrm{m}$ to $1.1 \mu \mathrm{m}$ \\
$2.1 \mathrm{~kW}-35 \mathrm{~min}$ & $0.8 \mu \mathrm{m}$ to $4.6 \mu \mathrm{m}$ & $2.1 \mathrm{~kW}-35 \mathrm{~min}$ & $0.6 \mu \mathrm{m}$ to $1.8 \mu \mathrm{m}$ \\
\hline
\end{tabular}

a bimodal grain size distribution, with small grains of secondary mullite and larger and more elongated primary mullite grains, which may be attributed to the presence of larger amounts of liquid phase during sintering and better coupling with microwaves. Compositions $\mathrm{S}$ and $\mathrm{A}$ showed a similar mullite grain morphology consisting of elongated and equiaxed grains. Moreover, it was found that the addition of alumina reduces the size of mullite grains and their aspect ratio. The excess alumina eliminated the $\mathrm{SiO}_{2}$-rich phase then retarded the anisotropic mullite grain growth at a sintering temperature around the eutectic point of mullite silica system.

According to the literature ${ }^{3,4}$, the morphology of mullite grains derived from silica-rich compositions is needle-like, while that of alumina-rich $\left(>10 \mathrm{wt} . \% \mathrm{Al}_{2} \mathrm{O}_{3}\right)$ compositions is more equiaxed and, in the case of naturally occurring raw materials, mullite derived from ball clay and china clay (kaolin) consists of elongated grains. The needle-like morphology of the mullite grains requires the presence of a liquid phase. Therefore, the results obtained here are consistent with the literature, although microwave fast firing produced finer and more homogeneous microstructures than conventional sintering.

The results obtained in this study demonstrated the successful use of fast microwave heating for the production

\section{References}

1. Schneider H, Schreuer J and Hildmann B. Structure and properties of mullite - A review. Journal of the European Ceramic Society. 2008; 28(2):329-344. http://dx.doi. org/10.1016/j.jeurceramsoc.2007.03.017. of mullite $-\mathrm{Al}_{2} \mathrm{O}_{3}$ by sintering. They also demonstrated that compositional variations that cause differences in sintering behavior during conventional sintering are highly significant in microwave processing.

\section{Conclusions}

This study evaluated the effect of non-stoichiometric compositions on the preparation of mullite by microwaveassisted fast reaction sintering of kaolin and alumina. The phase evolution indicated that mullitization occurred very rapidly in all the compositions; $30 \mathrm{~min}$ of microwave irradiation at 1.8 or $2.1 \mathrm{~kW}$ sufficed for the development of the reaction. However, a minor increase in the silica content improved the mullitization process and reduced the final density of the sintered body. Alumina-rich mullite showed higher densities and smaller grain size than alumina-poor mullite. The reaction sintering of mullite-alumina was very sensitive to composition in microwave processing.

\section{Acknowledgments}

The authors acknowledge the Brazilian agency CNPq (Proc. 472638/2008-4) and FAPESP (Proc. 07/59564-0) for its financial support of this work.

2. Roy J, Bandyopadhyay N, Das S and Maitra S. Role of V2O5 on the formation of chemical mullite from aluminosilicate precursor. Ceramics International. 2010; 36(5):1603-1608. http://dx.doi.org/10.1016/j.ceramint.2010.02.038.

3. Schneider $\mathrm{H}$ and Komarneni S. Mullite. 1st ed. Weinheim: Wiley-VCH Verlag GmbH \& Co. KGaA; 2005. 
4. Ganesh I and Ferreira JMF. Influence of raw material type and of the overall chemical composition on phase formation and sintered microstructure of mullite aggregates. Ceramics International. 2009; 35(5):2007-2015. http://dx.doi. org/10.1016/j.ceramint.2008.11.008.

5. Kalita PE, Schneider H, Lipinska K, Sinogeikin S, Hemmers OA and Cornelius A. High-Pressure Behavior of Mullite: An $\mathrm{X}$-Ray Diffraction Investigation. Journal of the American Ceramic Society. 2013; 96(5):1635-1642. http://dx.doi. org/10.1111/jace.12191.

6. Bagchi B, Das S, Bhattacharya A, Basu R and Nandy P. Mullite phase enhancement in Indian kaolins by addition of vanadium pentoxide. Applied Clay Science. 2010; 47(3-4):409-413. http:// dx.doi.org/10.1016/j.clay.2009.12.008.

7. Li J, Lin H, Li J and Wu J. Effects of different potassium salts on the formation of mullite as the only crystal phase in kaolinite. Journal of the European Ceramic Society. 2009; 29(14):29292936. http://dx.doi.org/10.1016/j.jeurceramsoc.2009.04.032.

8. Panneerselvam M and Rao KJ. Novel microwave method for the synthesis and sintering of mullite from kaolinite. Chemistry of Materials. 2003; 15(11):2247-2252. http://dx.doi. org/10.1021/cm0301423.

9. Viswabaskaran V, Gnanam FD and Balasubramanian M. Effect of $\mathrm{MgO}, \mathrm{Y} 2 \mathrm{O} 3$ and boehmite additives on the sintering behavior of mullite formed from kaolinite-reactive alumina. Journal of Materials Processing Technology. 2003; 142(1):275281. http://dx.doi.org/10.1016/S0924-0136(03)00577-6.

10. She J, Mechnich P, Schmücker M and Schneider H. Lowtemperature reaction-sintering of mullite ceramics with an Y2O3 addition. Ceramics International. 2001; 27(8):847-852. http://dx.doi.org/10.1016/S0272-8842(01)00039-6.

11. Ebadzadeh T, Sarrafi MH and Salahi E. Microwave-assisted synthesis and sintering of mullite. Ceramics International. 2009; 35(8):3175-3179. http://dx.doi.org/10.1016/j. ceramint.2009.05.013

12. Harmer MP and Brook RJ. Fast firing - Microstructural benefits. Transactions and Journal of the British Ceramic Society. 1981; 80:147-148.

13. Lin FJT, Jonghe LC and Rahaman MN. Initial coarsening and microstructural evolution of fast-fired and $\mathrm{MgO}$-doped $\mathrm{Al} 2 \mathrm{O} 3$. Journal of the American Ceramic Society. 1997; 80(11):28912896. http://dx.doi.org/10.1111/j.1151-2916.1997.tb03208.x.

14. Souto PM, Menezes RR and Kiminami RHGA. Microwave hybrid sintering of mullite powders. American Ceramic Society Bulletin. 2007; 86(1):9201-9206.

15. Menezes RR and Kiminami RHGA. Microwave sintering of alumina-zirconia nanocomposites. Journal of Materials Processing Technology. 2008; 203(1-3):513-517. http://dx.doi. org/10.1016/j.jmatprotec.2007.10.057.

16. Katz JD. Microwave sintering of ceramics. Annual Review of Materials Science. 1992; 22(1):153-170. http://dx.doi. org/10.1146/annurev.ms.22.080192.001101.

17. Clark DE and Sutton W. Microwave processing of materials. Annual Review of Materials Science. 1996; 26(1):299-331. http://dx.doi.org/10.1146/annurev.ms.26.080196.001503.
18. Agrawal DK. Microwave processing of ceramics. Solid State and Materials Science. 1998; 3(5):480-485. http://dx.doi. org/10.1016/S1359-0286(98)80011-9.

19. Menezes RR, Souto PM and Kiminami RHGA. Microwave hybrid fast sintering of porcelain bodies. Journal of Materials Processing Technology. 2007; 190(1-3):223-229. http://dx.doi. org/10.1016/j.jmatprotec.2007.02.041.

20. Thostenson ET and Chou TW. Microwave processing: fundamentals and applications. Composites. Part A, Applied Science and Manufacturing. 1999; 30(9):1055-1071. http:// dx.doi.org/10.1016/S1359-835X(99)00020-2.

21. Oghbaei M and Mirzaee O. Microwave versus conventional sintering: A review of fundamentals, advantages and applications. Journal of Alloys and Compounds. 2010; 494(12):175-189. http://dx.doi.org/10.1016/j.jallcom.2010.01.068.

22. Ebadzadeh T. Effect of mechanical activation and microwave heating on synthesis and sintering of nano-structured mullite. Journal of Alloys and Compounds. 2010; 489(1):125-129. http://dx.doi.org/10.1016/j.jallcom.2009.09.030.

23. Souto PM, Menezes RR and Kiminami RHGA. Effect of Y2O3 additive on conventional and microwave sintering of mullite. Ceramics International. 2011; 37(1):241-248. http://dx.doi. org/10.1016/j.ceramint.2010.08.043.

24. American Society for Testing and Materials - ASTM. ASTM C373-88 - Standard Test Method for Water Absorption, Bulk Density, Apparent Porosity, and Apparent Specific Gravity of Fired Whiteware Products. ASTM; 2006.

25. Liu K-C, Thomas G, Caballero A, Moya JS and Aza S. Timetemperature-transformation curves for kaolinite- $\alpha$-alumina. Journal of the American Ceramic Society. 1994; 77(6):15451552. http://dx.doi.org/10.1111/j.1151-2916.1994.tb09755.x.

26. Piluso P, Gaillard L, Lequeux N and Both P. Mullitization and densification of $(3 \mathrm{~A} 12 \mathrm{O} 3+2 \mathrm{SiO} 2)$ powder compacts by microwave sintering. Journal of the European Ceramic Society. 1996; 16(2):121-125. http://dx.doi.org/10.1016/09552219(95)00134-4.

27. Schneider H, Saruhan B, Voll D, Merwin L and Sebald A. Mullite precursor phases. Journal of the European Ceramic Society. 1993; 11(1):87-94. http://dx.doi.org/10.1016/09552219(93)90062-V.

28. Wang J, Binner J, Vaidhyanathan B, Joomun N, Kilner J, Dimitrakis G, et al. Evidence for the microwave effect during hybrid sintering. Journal of the American Ceramic Society. 2006; 89(6):1977-1984. http://dx.doi.org/10.1111/j.15512916.2006.00976.x.

29. Roy R, Peelamedu R, Hurtt L, Cheng J and Agrawal D. Definitive experimental evidence for microwave effects: radically new effects of separated $\mathrm{E}$ and $\mathrm{H}$ fields, such as decrystallization of oxides in seconds. Materials Research Innovation. 2002; 6(3):128-140. http://dx.doi.org/10.1007/ s10019-002-0199-x.

30. Ebadzadeh T. Formation of mullite from precursor powders: sintering, microstructure and mechanical properties. Materials Science and Engineering. 2003; 355(1-2):56-61. http://dx.doi. org/10.1016/S0921-5093(03)00049-2. 